\title{
Non-verbal samhandlingskompetanse i munnleg forteljarkunst
}

Av Kristin Aadland-Atkinson, høgskolelektor ved NLA Høgskolen og PhDkandidat ved Institutt for pedagogikk, Universitetet i Oslo.

\section{Samandrag}

Artikkelen utforskar verdien av non-verbal samhandlingskompetanse, og munnleg forteljarkunst som ein veg inn til denne. Læreplanverket til kunnskapsløftet føreset arbeid med munnleg ferdigheit, både formidling, lytting og forståing. I møtet mellom forteljar og tilhøyrarar skjer det ein interaksjon mellom forteljar, forteljing og tilhøyrar, der verbal og non-verbal formidling og lytting står sentralt. I denne artikkelen vert dette møtet belyst med følgjande problemstilling: Korleis kan ungdomar gjennom kurs i munnleg forteljing erfara og utvikla non-verbal samhandlingskompetanse? Artikkelen byggjer på intervju med fleirkulturelle elevar på niande trinn som er erfarne lyttarar, og som har teke del i eit forteljarkurs. Rundt 70 elevar deltok på kurset, og studien følgjer seks elevar, som er intervjua i etterkant, både om kurset, og om tidlegare erfaringar med lytting til forteljing. Funn er analysert og drøfta i lys av sosiokulturell teori, og teori om munnleg forteljing, munnleg ferdigheit, retorikk og multimodalitet. Sentrale funn syner at elevane har eit medvit om munnleg forteljing som ein multimodal aktivitet, der non-verbale og verbale modalitetar utfyller kvarandre, og der forteljaren gjennom bruken av dei ulike modalitetane har ansvar for tilhøyraren si oppleving. På denne måten erfarer og utviklar elevane samhandlingskompetanse, gjennom arbeidet med den munnlege forteljinga.

Nøkkelord: Non-verbal samhandlingskompetanse, forteljarkunst, ungdom 


\section{Abstract}

The article explores the value of non-verbal interactive skills, and the art of oral storytelling as a way into these skills. The Norwegian curriculum (the Knowledge Promotion Reform) presupposes working on oral skills, both telling, listening and understanding. In the meeting between storyteller and listeners interaction happens between storyteller, story and listener, where verbal and non-verbal dissemination and listening is central. In this article this meeting is enlightened with a research question as follows: How can youths through a course in oral storytelling experience and develop nonverbal interactive skills? The article is based on interviews with multicultural youths in the ninth year in a lower secondary school in Norway. They are experienced listeners, and had just before the interviews taken part in a storytelling course. About 70 students participated in the course, and the study follows six students, who are interviewed in hindsight, both about the course, and about earlier experience with listening to storytelling. Findings are analyzed and discussed in the light of socio cultural theory and theory about oral storytelling, oral skills, rhetoric and multimodality. Central findings suggest that the students have awareness about oral storytelling as a multimodal activity, where non-verbal and verbal modalities complete each other, and where the storyteller through the use of the different modalities has the responsibility for the listener's experience. In this way, the students experience and develop interactive skills, through their work with oral storytelling.

\section{Introduksjon}

Denne artikkelen handlar om utvikling av non-verbal samhandlingskompetanse i tileigning av munnleg forteljarkunst, med eit fokus på behovet for kompetent rettleiing. Omgrepet samhandlingskompetanse er vektlagt i Ludvigsen-utvalet sin rapport om endring av forståing av kompetanse i skulen (NOU 2015:8, 2015), som avgjerande for å kunna delta og bidra i eit demokratisk og mangfaldig samfunn. Ludvigsen-utvalet knyter den gjensidige interaksjonen i den munnlege situasjonen, til samhandlingskompetanse og 
seier at elevane må læra samhandling i ulike munnlege sjangrar, og å reflektera over eigen munnleg kommunikasjon.

Munnleg ferdigheit vart teken inn som ein av fem grunnleggjande ferdigheiter i Læreplanverket for kunnskapsløftet, LK06 (Utdanningsdirektoratet, 2006, 2013, 2020) og skal arbeidast med i alle fag. Desse ferdigheitene er i rammeverket (Utdanningsdirektoratet, 2017) mellom anna vektlagde som sentrale i utvikling av sosiale relasjonar, og for å kunna delta på ulike arenaer i samfunnet. Elevane skal læra å meistra ulike språklege handlingar, samordna verbale ferdigheiter og andre delferdigheiter og «kunne lytte til andre og gi respons og være bevisst på mottakeren når en taler selv» (Utdanningsdirektoratet, 2017, s. 6). Munnleg ferdigheit vert definert som å kunna "skape mening gjennom å lytte, tale og samtale» (Utdanningsdirektoratet, 2017, s. 6).

I tidlegare læreplanar skal elevane etter andre trinn kunna «fortelle sammenhengende om opplevelser og erfaringer» (Utdanningsdirektoratet, 2013, s. 6). Forteljing er her rekna som ein primærdiskurs - ein kvardagsdiskurs som elevar lærer før skulestart (Aksnes, 2016). I rammeverket er det først og fremst på lågare trinn at forteljinga er nemnd som døme på munnleg ferdigheit (Aksnes, 2016). Eg argumenterer i denne artikkelen for at ungdom med samansett kulturell bakgrunn kan lære munnleg ferdigheit og dermed samhandlingskompetanse gjennom kurs i munnleg forteljarkunst. Dette byggjer på Bruner sitt argument om at narrativ kompetanse er noko ein må øva på gjennom heile skuleløpet, for å konstruera eigen identitet og finna ein plass i den kulturen ein skal vera ein del av (Aksnes, 2016; Bruner, 1997).

Studien eg refererer til her, følgjer ungdommar som er vane med å lytta til forteljing, og som tek del i eit forteljarkurs. Profesjonelle forteljarar var instruktørar og rettleiarar. Elevane konstruerte forteljingar basert på eigenopplevde hendingar, og fekk instruksjon og rettleiing både på innhald, form og formidling. Det empiriske materialet er intervju med nokre av elevane. Analysen fokuserer på form og formidling og delferdigheitene, som dei verbale ferdigheitene skal samordnast med (Utdanningsdirektoratet, 2017). Munnleg forteljing skjer utan andre hjelpemiddel enn eigen kropp og stemme, og dermed er det den non-verbale formidlinga som vert dei «andre delferdigheitene». Problemstillinga er difor: 
Korleis kan ungdomar gjennom kurs i munnleg forteljing erfara og utvikla non-verbal samhandlingskompetanse?

\section{Munnleg forteljarkunst og kompetanse}

Munnleg forteljing er ei eldgamal formidlingsform, og samstundes ei ny kunstform. I vesten har interessa for munnleg forteljing teke seg opp sidan slutten av 1900-talet (Dahlsveen, 2008; Pellowski, 1990). Ved fleire norske studiestader kan ein i dag, som del av dramafaget, studera munnleg forteljing. Fleire lever av å fortelja, og skulen har blitt ein arena for munnlege forteljarar.

Ein munnleg forteljar er her forstått som ein kunstnarisk utøvar som utan bok, og utan ordrett pugging, fortel ei forteljing, basert på folkedikting, litterær dikting, eigen fantasi, eller eiga erfaring (Dahlsveen, 2008; Pellowski, 1990). Ein nedskriven tekst kan - men må ikkje - liggja til grunn for forteljinga. Innlæring skjer gjerne gjennom ulike øvingar der fokus ligg på å læra sekvensane i forteljinga i form av indre bilete av landskap, karakterar og hendingar. Det er desse bileta, som skal formidlast vidare - verbalt og non-verbalt (Samset, 2010). Når utgangspunktet er eigenopplevde forteljingar, vert utval av innhald og oppbygginga av forteljinga ein endå større del av forarbeidet.

Svenkerud (2013) konkluderer med at elevar som reflekterer over arbeid med munnlege presentasjonar har lite fokus på lyttarrollen. Elevane er opptekne av stemmebruk og kroppsspråk, med fokus på eigen framtoning. Lytting tyder for elevane å følgja med, og presentasjonen si form og formidlaren sitt ansvar for å få lyttarane til å følgja med er ikkje poengtert i rettleiinga lærarane tilbyd. Svenkerud argumenterer for at den munnlege presentasjonen er ein kompleks prosess, og for å få til samhandling treng elevane «kunnskap om innhold, form, kommunikativ kompetanse og retoriske ferdigheter» (2013, s. 12). Studien antyder at lærarar ikkje vektlegg den munnlege ferdigheita nok i rettleiinga av elevane sine munnlege presentasjonar, og med dette også lyttinga. Lytting er ein vesentleg del av den non-verbale samhandlingskompetansen, og munnleg ferdigheit og lytting inkluderer performativ kompetanse i å få den andre til å følgja med. 
Med utgangspunkt i problemstillinga vil eg i det følgjande konstruera eit teoretisk rammeverk, der munnleg forteljing vert sett i lys av sosiokulturell teori, og teori og forsking om munnleg forteljing, munnleg ferdigheit, retorikk og multimodalitet. Vidare kjem ei utgreiing av metode. Under overskrifta funn og drøfting presenterer eg tre hovudfunn, og drøftar desse mot teori og forsking, før eg konkluderer.

\section{Teoretisk rammeverk}

\section{Forteljing, erfaring og samkonstruksjon}

Alle forteljingar byggjer på erfaringar. Erfaringane kan vera forteljaren sine eigne, eller gjort til forteljaren sine gjennom forteljing (Benjamin, 1969). For at ei rekkje hendingar skal bli ei forteljing, må hendingane knytast saman med eit opplevd årsaksforhold (Bruner, 1986). Gjennom ein narrativ tenkemåte organiserer me erfaringane våre som forteljingar for å skapa samanheng og meining i det me erfarer. Dette skjer allereie frå me er små (Bruner, 1986; Vygotsky, 2004).

I ei eg-forteljing, er forteljaren sjølv protagonist. For å finna interessante forteljingar arbeider ein gjerne med teknikkar for å velja ut minne som kan gjevast ein forteljingsstruktur og bli ei forteljing (Dahlsveen, 2014). Når konstruksjon av meining skjer i ei gruppe, med rettleiing, kan ein seia at læring skjer som ein sosial prosess, saman med signifikante andre, i den nærmaste utviklingssona - dit individet kan strekkja seg med støtte frå signifikante andre (Vygotsky, 1978). Ein slik prosess kan me kalla samkonstruksjon (Van der Veer \& Valsiner, 1988). I vårt tilfelle skjer det ei utvikling av ei personleg forteljing i ei gruppe, og med rettleiing. Forteljingane byggjer på personlege minne, men vert konstruerte i eit fellesskap. Trass i samkonstruksjonen vert forteljinga ståande som forteljaren si. Ifølgje Benjamin, vil likevel den som lyttar ta del i erfaringane som vert fortalde. 


\section{Munnleg forteljing som multimodal, performativ og ein retorisk ferdigheit}

Mennesket kommuniserte med kropp og stemme før talespråket vart utvikla, og barnet kommuniserer slik før det utviklar språket (Säljö, 2006; Vygotsky, 1978). Seinare utfyller gestar og stemmebruk talespråket og er del av den munnlege handlinga, for born og vaksne (Olson, 2006). Når den munnlege forteljinga skal framførast, vert det ei performativ handling, der ulike modalitetar vert brukte i samhandlinga med tilhøyrarar, og med forteljinga som ligg til grunn (Bauman, 1986; Lwin, 2010, 2016, 2017; Swann, 2002; Aadland, 2016). Verbale (ord, uttrykksformer), vokale (stemme, tonefall, trykk) og visuelle modalitetar (gestar, ansiktsuttrykk) vert nytta i performativ iscenesetjing av karakterar og handling (Swann, 2002). Dei kan også nyttast for å styra tilhøyrarane si meiningsdanning (Lwin, 2010), forklara vanskelege ord (Lwin, 2016), eller i samkonstruksjon av forteljing mellom forteljar og tilhøyrarar (2017). Aadland (2016) studerer korleis ein forteljar bruker verbale, vokale og visuelle trekk til å invitera førsteklassingar inn i ei performativ samhandling med henne og forteljinga. Samhandlinga er situasjonsbestemt, og skjer innanfor det som Bauman (1986) kallar «the narrative event»: forteljarsituasjonen.

Den situasjonsavhengige munnlege situasjonen gjer det vanskeleg å skilja talaren frå bodskapen (Høisæter, 1997; Olson, 2006; Ong, 1990). Alt frå påkledning til stemme, mimikk og gestar påverkar tolkinga av det språklege innhaldet, og talaren vert meir sårbar for kritikk. Dette kan vera ei forklaring på at det munnlege har fătt liten plass i skulen, og at lærarar vegrar seg for å gje respons på form i munnlege presentasjonar (Aksnes, 2016). For den munnlege forteljaren inneber denne nærleiken at ho må kunna stå for forteljinga, og det ligg i tillegg eit ansvar hos forteljaren for å «lytta» til tilhøyrarane og passa på at dei er med (Aadland, 2016; Nesje, 2004). Denne lyttinga er ein del av den performative forteljarkompetansen.

Ei performativ munnleg forteljing, slik det er forstått her, er ein planlagt situasjon. Det ligg ein plan bak mykje av både verbal og non-verbal handling i forteljarsituasjonen. Difor kan ein samanlikna den munnlege forteljarkunsten med den munnlege talen, eller talekunsten, som retorikken omhandlar (Andersen, 2000; Bakken, 2009; Liset, 2002). Likevel held samkonstruksjonen fram i interaksjonen med tilhøyrarane (Aadland, 2016, Aadland-Atkinson og Stuedahl, 2020). 
Sentralt i retorikken står at ein skal overtyda tilhøyraren (Bakken, 2009). Dette krev planlegging. Arbeid med språk, som også krev tid og planlegging, er avgjerande for nettopp å læra retoriske ferdigheiter (Aksnes, 2016). I den munnlege forteljarsituasjonen skal forteljaren overtyda gjennom å formidla og stimulera indre bilete og engasjement for forteljinga si (Dahlsveen, 2008; Samset, 2010; Sturm, 2008). Gjennom planlagde verbale og non-verbale uttrykk, får ein fram både handlingsforløpet, og det som skal til for at tilhøyraren skal få ei kjensle av å dela erfaringane som vart formidla (Benjamin, 1969).

Actio i retorikken - framføringa av talen - er nettopp arbeidet med det non-verbale. I retorisk teori finst det detaljerte utgreiingar av ulike gestar, mimikk og stemmeintonasjon som skal uttrykka ulik meining (Andersen, 2000; Bakken, 2009). Eg vel i analysen å bruka omgrepet visuell modalitet om det som har med actio, kroppsspråk, gestar og mimikk å gjera, og vokal modalitet om det som har med stemme, intonasjon, pause med meir. Dette er i tråd med analysane til Swann (2002), Lwin $(2010,2016,2017)$ og Aadland (2016).

Lwin (2016) føreslår at forteljaren ved medviten bruk av verbale, visuelle og vokale modalitetar held tilhøyraren fast i forteljaropplevinga på ein annan måte enn ved verbal forklaring, som kanskje oftare førekjem i høgtlesingssituasjonar. Avhengig av korleis forteljar og forteljing treff tilhøyraren, kan tilhøyraren oppleva å leva seg inn på ein slik måte at oppleving av tid og rom vert endra (Kuyvenhoven, 2009; Sturm, 1999, 2000, 2002). Dette er individuelle og situasjonsbundne opplevingar, som kan knytast til det spesifikke møtet mellom forteljar, forteljing og den einskilde tilhøyraren. Ei oppleving av innleving, kan gjera noko med elevane sitt engasjement for forteljing. Forteljarar som vart intervjua om erfaringar med å fortelja for yngre skuleelevar (Aadland, 2009), opplevde at elevar kunne koma bort til dei og fortelja att forteljingar som dei hadde høyrt, lang tid etter ei forteljarstund. Dette tyder på at engasjement for forteljing, og erfaringa tilhøyraren sit igjen med, kan knytast til den performative kompetansen til forteljaren. 


\section{Metode, kontekst og informantar}

Med ei fenomenologisk tilnærming (Postholm, 2005; Vettenranta, 2005) studerer eg munnleg forteljing slik det utspelar seg i ein norsk ungdomsskule, frå elevane sin ståstad. Skulen er ein kombinert barne- og ungdomsskule, som har hatt fast avtale med forteljar sidan før desse elevane starta skulegangen. Elevane i studien har lang erfaring med å lytta til forteljingar. Dei har nyleg lært å fortelja sjølve, gjennom eit forteljarkurs som enda med ei framsyning, der dei fortalde eigenopplevde forteljingar. Kurset var arrangert av skulen og fire forteljarinstruktørar. Elevane var 15 år gamle og hadde blanda kulturell bakgrunn. Eg hadde før kurset informert om forskingsprosjektet på eit foreldremøte, og delt ut skriftleg informasjon med samtykkeerklæring, som foreldra signerte der og då. Prosjektet er godkjent av NSD.

Forteljarkurset varte i fire fulle, samanhengande skuledagar. Det enda med felles framsyning for medelevar, foreldre og lærarar den siste kvelden. Det var omlag 70 elevar på trinnet. Gjennom kursdagane og framsyninga var gruppa delt i to. Etter ein introduksjon med arbeid for å finna minne som skulle bli til forteljingar, vart dei delt i mindre grupper etter tema. Under framsyninga gjekk kvar gruppe samla opp på scenen, men elevane fortalde enkeltvis for eit relativt stort publikum.

Gjennom kurset følgde eg først den eine halve gruppa, og deretter ei temagruppe på ti elevar. Eg hadde ein tilnærma ikkje-deltakande observatørrolle (Fangen, 2010), gjennom kurset og påfølgjande framsyning. Intervju av seks av dei ti elevane i temagruppa utført eit par veker etter gjennomført kurs og framsyning dannar datagrunnlag her. Intervjupersonane har som eit ledd i anonymiseringa fått fiktive namn. Dei som er intervjua er tre jenter: Naheed, Isa og Samira, og tre gutar: Caalim, Jasin og Rebin. Dei fleste av intervjupersonane hadde gått på skulen frå starten, medan nokre hadde kome til undervegs.

Intervjuet var semistrukturert med ein tematisk inndelt intervjuguide, med rom for improvisasjon (Kvale \& Brinkmann, 2015). Intervjua vart haldne i grupperom tilknytt klasserommet til elevane, og kvart intervju varte i 12-20 minutt. Eg transkriberte intervjua ved bruk av eit enkelt system med elipseteikn for pausar, og elles talegjengjeving på tilnærma bokmål, fordi 
dette er nærare elevane sitt talemål. I analysen har eg teke utgangspunkt i transkripsjonane, og gått tilbake til lydopptak for å sjekka for uklarheiter.

\section{Sentrale funn og drøfting}

Gjennom gjennomlesingar og koding av intervju har tre funnkategoriar skilt seg ut som sentrale for å belysa korleis ungdom kan erfara og utvikla nonverbale modalitetar og samhandlingskompetanse gjennom kurs i munnleg forteljing: Forståing av vokale og visuelle modalitetar, forståing av førebuing og rettleiing, og forståing av ansvaret for å få med seg tilhøyraren. I det følgjande vil eg analysera og drøfta samanheng mellom data og teori under kvar kategori.

\section{Forståing av vokale og visuelle modalitetar}

Elevane i forteljarkurset øvde på å samordna visuelle og vokale modalitetar med verbale modalitetar, gjennom praktisk øving og rettleiing. I forteljing, som i retorikk og annan performativ kunst, arbeider ein medvite med det non-verbale som ein del av den naturlege kommunikasjonen. Om elevane beherskar denne samankoplinga når dei fortel sjølve er ikkje studert her, men me ser at dei reflekterer over samanhengen.

På spørsmål om kva som kjenneteiknar ein god forteljar, vektlegg alle informantane dei visuelle og vokale modalitetane. Jasin framhevar at forteljaren må ha gode og gjennomtenkte rørsler. Han fortel at han har erfart at gestar kan illustrera det som vert sagt, og syner at han har forstått samanhengen mellom visuell og verbal modalitet:

- Du vet ... når jeg hører på en mann fortelle en fortelling, så pleide jeg ikke å merke at han beveger seg og sånt (...) Men etter fortellerkurset, så begynte jeg å legge merke til de bevegelsene.

Han fortel vidare at gestar kan forstyrra, dersom dei ikkje høver saman med det som vert sagt, og at han har byrja å leggja merke til dette hos andre, og hos seg sjølv, i ulike samanhengar. 
Intervjupersonane bruker ulike uttrykk for å forklara det visuelle og det vokale. Isa framhevar at tonefallet og kroppsspråk er viktig. Rebin snakkar om å ha «bevegelse i kroppen». Det gjer også Naheed. Ho knyter rørsla til det å kunna forteljinga godt, og leva seg inn når ein fortel.

Caalim syner at visuell og vokal modalitet både skal utfylla det verbale, og levandegjera forteljinga:

- ... man skal bevege litt på seg når man forteller. Gjøre historien levende - ikke bare snakk, snakk, snakk, så alle begynner å sovne ... kjedelig.

Alle dei tre modalitetane har vore vektlagde i rettleiinga. Likevel synest intervjupersonane jamt over mest opptekne av særleg den visuelle modaliteten, men også den vokale. Det kan tyda på at desse var mindre kjende for dei enn den verbale modaliteten, og at erfaringar frå kurset førte til nye refleksjonar rundt det som var nytt. Ungdomane stadfestar ei forståing av det nonverbale som ein naturleg del av den verbale formidlinga, både i kvardagsleg kommunikasjon som ein naturleg del av verbal utvikling, og i den planlagde forteljinga, eller actio. Dei har erfart kor viktig det er at det verbale og det non-verbale jobbar saman, og at det påverkar den erfaringa den einskilde tilhøyraren sit igjen med - både i forteljing og anna munnleg samhandling.

Den medvitne bruken av verbale, visuelle og vokale modalitetar saman kan slik elevane uttrykker det, støtta forståinga av det som vert formidla. Dette kan me sjå i samanheng med teori om samkonstruksjon av meining av narrativ og av samhandlingssituasjon, som kan bidra både til ei sams oppleving og ei individuell forståing. Dette er støtta av mellom andre AadlandAtkinson og Stuedahl (2020) som studerer korleis førsteklassingar snakkar om, og hugsar forteljinga etter ei forteljarstund. Det einskilde barnet si deltaking og interaksjon med forteljar og forteljing gjennom verbale, visuelle og vokale modalitetar, synest å vera med på å fremja forståinga og konstruksjonen dei sit igjen med, som dei seinare formidlar i intervjusituasjonen.

\section{Forståing av forebuing og rettleiing}

Den munnlege forteljinga er som den retoriske talen og annan performativ kunst, ei planlagd framføring. Fleire av intervjupersonane fekk gjennom forteljarkurset syn for arbeidet bak det å fortelja bra. Gjennom erfaring synest 
dei å ha fått innsikt i performativ munnleg forteljing som ein situasjon som skal røra og, som retorikken seier det, overtyda tilhøyraren.

Isa løftar fram at forteljaren må gjera meir enn det ser ut til. Ho fekk ei aha-oppleving då ho erfarte dette på kurset:

- Når man forteller selv føler man hvor vanskelig det egentlig er

Naheed seier at forteljaren må

- ... kunne fortellingen veldig godt. Kan du ikke den, så er det ikke vits i å fortelle en gang. Siden du må fortelle med følelser ... du må fortelle bra. Så ... publikum liksom forstår det.

Jasin framhevar at ein god forteljar bruker dei ulike modalitetane, og førebur seg grundig:

- Jeg trodde før at man skal sitte og fortelle noe, fra... fra... noe som man har hørt fra før av... Men det er ikke det. Du må øve og så må du... på en måte få med publikum.

Publikum får ein med seg ved at ein «beveger seg og sånt». Dei visuelle og vokale modalitetane vert såleis også ein viktig del av det ein øver på, og får rettleiing på.

På spørsmål om kva som gjer ei forteljing god, svarar Samira:

- Egentlig fortelling ... den som forteller (...) hvordan stemmebruk og kropps... hvordan du bruker kroppen og sånne ting.

Caalim svarar at forteljing blir bra ved at historien er bra, men også:

- Hva de snakker om og hvordan ... jeg syns stemmebruk. For meg så er det stemmebruk, da, det er det jeg syns er bra.

Her bringer begge inn eit lag til: ved å bruka visuelle og vokale gjer forteljaren forteljinga god. Dette framhevar nærleiken mellom munnleg forteljing og forteljaren. Forteljaren og forma gjer, saman med innhaldet, forteljinga spennande. 
Alle intervjupersonane snakkar positivt om kurset dei har delteke på. Dei synest samde om at det var nyttig å fortelja mange gonger, og å få tilbakemeldingar på forteljinga. Fleire seier at det var lettare å fortelja for forteljarane enn for medelevane. Noko av det siste dei gjorde på kurset, var å få individuelle tilbakemeldingar frå forteljar, i einerom. Dette framheldt alle som positivt og lærerikt, sjølv om ikkje alle var sikre på om dei hadde hugsa alt då dei stod på scenen.

Caalim fekk særleg utbyte av å fortelja for forteljaren. Han fekk innsikt i korleis øving med respons på både innhald og utføring, vart effektiv:

- før pleide bare lærerne å si (...) «du må snakke foran speilet» (...) Og det trodde jeg ikke hjalp, så jeg pleide bare å lese noen ganger (...) Så jeg lærte at for å øve skikkelig må du presentere den for noen andre.

Naheed ser også verdien av førebuing for å meistra dei ulike modalitetane:

- Dette gikk jo mer på selvtillit (...) Har du selvtilliten så kan du fremføre hva som helst foran hvem som helst.

Svenkerud etterspør lærarinstruksjon og deira rettleiing på elevens formutvikling. Når Caalim viser til lærarane som bad dei gå heim og «snakke foran speilet», kan det også sjåast som eit uttrykk for at rettleiing på form ikkje skjer, men at form blir eleven sitt eige ansvar. Det som vart avgjerande for han var å fortelja for andre, og få respons i situasjonen og tilbakemelding etterpå. Ved den erfaringa lærte han også at øving hjelper. Aksnes hevdar at nærleiken mellom talar og bodskap kan gjera det vanskeleg for lærarar å gje tilbakemelding på form. Med utgangspunkt i at desse elevane fortel eigenopplevde forteljingar, kan ein tenkja seg at bandet mellom talar og bodskap vert ekstra sterkt. Elevane i studien har som gruppe og einskildindivid fătt rettleiing både på form og innhald. Dette kunne tenkjast å vera ekstra sårbart, sidan instruksjon på innhald også tyder omarbeiding av eigne minne. Elevane gir likevel uttrykk for at dei sette pris på den individuelle rettleiinga undervegs. Dei seier denne også gjorde det lettare å stå på scenen med tryggleik og sjølvtillit for det dei skulle prestera. Det kan ha hatt noko å seia for opplevinga at instruksjonen kom frå personar som dei kjende som gode forteljarar. Forteljarane er profesjonelle, og kjende med kva som trengst av øving 
og tilbakemelding for å prestera på scenen, og det veit elevane. Det kan også vera at vekslinga mellom den individuelle og gruppevise rettleiinga undervegs er ei årsak til den gode opplevinga. Hos fleire av intervjupersonane synest rettleiinga å ha ført til refleksjonar som også gjorde dei kritiske til eigen prestasjon på scenen. Dermed kan dei sjølve bidra til eiga vurdering av form, og ein kan unngå noko av det vanskelege i å gje respons.

\section{Forståing av ansvaret for å få med seg tilhøyraren}

Den gjensidige lyttinga mellom forteljar og tilhøyrar er eit viktig element ved munnleg forteljarkunst, og eit uttrykk for den samhandlinga som skjer. På ulikt vis vektlegg alle informantane forteljaren sitt ansvar for å leva seg inn i forteljinga for å få tilhøyraren med seg inn. Caalim si utsegn om å røra på seg og gjera forteljinga levande og fortelja bra for å unngå at det berre blir snakk, er eit døme. Også Rebin snakkar om tilhøyraren:

- Vi lærte (...) hvordan vi skal bevege kroppen vår. Så vi må ... gjør ... gjøre at de andre ... føler seg inni vår historie ...

Bruken av dei ulike modalitetane vert avgjerande for å få med seg tilhøyraren.

To intervjupersonar framhevar blikkontakten som viktig. Caalim seier:

- Han [forteljaren] har bra sånn der øyekontakt med alle andre, på publikum...

Naheed seier at ein god forteljar greier å

- se i hver og en av dems øyne på en eller annen rar måte, og få dem med, bare sånn

Slik kan forteljaren sikra kontakten med tilhøyrarane, få dei til å kjenna seg inkluderte, sjå etter reaksjonar, og respondera på desse i den vidare forteljinga.

Ansvaret forteljaren har er også framheva når Samira seier: 
- Hvis det liksom blir litt kjedelig, så bare hører jeg på men ikke ser liksom, bare hører, og så etterpå, hvis det kommer noe spennende, så begynner jeg å følge med litt mer ...

Når det gjeld rollen som tilhøyrarar, er det også fleire som nemner at dette kjem an på forteljaren og forteljinga. Det er lettare å lytta når det er spennande: Når forteljaren og forteljinga engasjerer. Då er det fleire av dei som ser for seg det som skjer. Caalim uttrykkjer det slik:

- Jeg får historien liksom inn i hodet mitt.

Intervjupersonane har erfart at lytting, det å vera stille og ikkje forstyrra forteljar eller medelevar, er viktig. På spørsmål om kva som er viktig å tenkja på som tilhøyrar, kjem Jasin inn på tilhøyraren sitt ansvar i relasjonen.

- Å være stille ... Og virke interessert. Fordi at, på en måte, hvis alle virker sånn uinteressert, så de følger ikke med og sånt ... og.. han som forteller eventyret sitter og forteller, så mister han på en måte litt sånn selvtillit

Naheed framhevar i tillegg:

- Bare være inni fortellingen. Ha hodet klart til å forestille deg noe, rett og slett

Som tilhøyrar har ein altså sjølv eit ansvar for interaksjonen og for å koma inn i forteljinga, og leggja til rette for eiga innleving og dermed deltaking $\mathrm{i}$ samhandling. Denne sida var ikkje særleg fokusert under kurset, så det er sannsynleg at svara dei har gjeve er basert på deira erfaring med vektlegging av lytting, som tilhøyrarar i forteljarstundene med forteljarane.

I retorisk teori er talaren sitt ansvar for å overtyda tilhøyraren vektlagd. Forteljarteori har fokus på å skapa dei indre bileta for såleis å dra tilhøyraren inn i forteljinga, gjerne slik at oppleving av tid og rom vert oppheva. Gjennom erfaringane ved å lytta har fleire av intervjupersonane erfart å få slike indre bilete, men også at oppleving av innleving er skøyr. Med erfaring frå forteljarkurset har dei forstått kor viktig engasjement og innleving, gjennom mellom anna dei visuelle og vokale modalitetane er, for opplevinga 
tilhøyraren har under forteljinga, og kva erfaringar dei sit igjen med etterpå - ikkje berre sjølve lytteerfaringa, men dei erfaringane som ligg bak, og som er delte gjennom forteljinga. Interaksjonen mellom forteljar og tilhøyrar, ved bruk av dei ulike modalitetane, er undersøkt av fleire gjennomgåtte studiar, mellom anna hos yngre born av Aadland (2016).

\section{Konklusjon}

I denne artikkelen prøver eg å svara på korleis ungdom gjennom kurs i munnleg forteljing kan erfara og utvikla non-verbal samhandlingskompetanse. Visuelle og verbale modalitetar, saman med den verbale modaliteten, inngår i talaren og tilhøyraren sin samhandlingskompetanse. Forteljinga er, med utgangspunkt i både Benjamin, Vygotsky og Bruner, uttrykk for erfaringar, samstundes som erfaringane vert gjevne vidare til mottakar gjennom forteljarsituasjonen. Me har eit naturleg driv for å fortelja, men me treng å læra den narrative diskursen. Når forteljinga blir framført munnleg, vil det non-verbale allid vera med, som ein del av denne diskursen.

Ungdomane som deltok på forteljarkurset hadde alle erfaring som tilhøyrarar av munnleg forteljing. Gjennom kurset fekk dei erfaring med konstruksjon av forteljing og med framføring av ei personleg forteljing. Dei har også erfart korleis visuell modalitet og vokal modalitet utfyller, utdjupar og forsterkar det verbale og gir rom for å forsterka opplevinga av ei forteljing. Dei har vidare erfart verdien av kompetent rettleiing i planleggingsprosessen, og dei har erfart kor viktig det er å lytta til tilhøyraren og få denne med seg. Dermed kan me seia at gjennom erfaring med rettleiing og utprøving i prosessen med å utvikla forteljarframsyning i eit kurs, har ungdomane også fått erfaring med og utvikla non-verbal samhandlingskompetanse.

Rettleiinga i forteljarkurset vart gjeven av profesjonelle forteljarar som kan faget sitt, og som veit noko om kva som fungerer når ein til dømes skal $ø$ va. Lærarar si rettleiing på forma i munnlege presentasjonar har vore etterlyst, og det har vorte stilt spørsmål ved om nærleiken mellom talar og bodskap i ein munnleg læresituasjon gjer det vanskeleg å gje konstruktive tilbakemeldingar. Kanskje er det kunnskap om omfanget av munnleg ferdigheit, og rettleiing på denne som manglar i skulen? Med støtte i Bruner, så treng 
elevane opplæring i den narrative diskursen. Det gjeld truleg også annan munnleg diskurs, og dette vil difor vera relevant for framtidig lærarutdanning.

Ludvigsen-utvalet framhevar samhandlingskompetanse som ein viktig del av munnleg kompetanse, og i rammeverket for grunnleggjande ferdigheiter er lytting og medvit om tilhøyraren tekne med som ein del av den munnlege ferdigheita. Med aukande omfang av munnlege framføringar i skulen kan ein ikkje forventa slike prosessar som eit forteljarkurs er, kvar gong. Det er likevel grunnlag for fleire studiar i korleis gje rettleiing på munnleg ferdigheit. Og det ville vera interessant å gå vidare med dei erfaringane om nærleik og rettleiing som har blitt skisserte her, og sjå om noko av dette kunne overførast til arbeid med munnleg ferdigheit - og samhandlingskompetanse.

\section{Litteratur}

Aksnes, L.M. (2016). Om muntlighet som fagfelt. I: K. Kverndokken (red.). 101 måter å fremme muntlige ferdigheter på. Om muntlig kompetanse og muntlighetsdidaktikk. Bergen: Fagbokforlaget Vigmostad og Bjørke.

Andersen, Ø. (2000). I retorikkens hage (3 utg.). Oslo: Universitetsforlaget. Bakken, J. (2009). Retorikk i skolen. Oslo: Universitetsforlaget.

Bauman, R. (1986). Story, performance, and event: Contextual studies of oral narrative (bd. 10). Cambridge: Cambridge University Press.

Benjamin, W. (1969). Illuminations. London: Vintage Books.

Bruner, J.S. (1986). Actual minds, possible worlds. Cambridge, Mass.: Harvard University Press.

Bruner, J.S. (1997). Utdanningskultur og lering. Oslo: Ad notam Gyldendal. Dahlsveen, H. (2008). Innforingsbok i muntlig fortellerkunst. Oslo: Universitetsforlaget.

Dahlsveen, H. (2014). Fellesskapet og estetikken løfter minnet. Den personlige fortellingen i voksenopplæringen. Drama. Nordisk dramapedagogisk tidsskrift, 51(01), 50-54.

Fangen, K. (2010). Deltagende observasjon. Bergen: Fagbokforlaget. 
Høisæter, S. (1997). Soga om Abraham og Isak - forteljaren vert sett på prøve. Norsklereren: tidsskrift for språk og litteratur, 21(5), 13-21.

Kuyvenhoven, J. (2009). In the presence of each other: a pedagogy of storytelling. Toronto: University of Toronto Press.

Kvale, S. \& Brinkmann, S. (2015). Det kvalitative forskningsintervju. Oslo: Gyldendal Akademisk.

Liset, M.S. (2002). Fem faser fortellerkunst. Et forsøk på retorisk begrepsliggjøring av en fortellerpraksis. (Hovedfagsoppgave). Bergen: Høgskolen i Bergen.

Lwin, S.M. (2010). Capturing the dynamics of narrative development in an oral storytelling performance: A multimodal perspective. Language and Literature, 19(4), 357-377.

https://doi.org/10.1177/0963947010373029

Lwin, S.M. (2016). It's story time!: exploring the potential of multimodality in oral storytelling to support children's vocabulary learning. Literacy, 50(2), 72-82.

Lwin, S.M. (2017). Narrativity and creativity in oral storytelling: Co-constructing a story with the audience. Language and Literature, 26(1), 3453.

Nesje, S.B.Ø. (2004). “А lytte med det tredje øret”: en muntlig fortellers refleksjon over egen praksis (Hovedfagsoppgave). Trondheim: NTNU.

NOU 2015:8. (2015). Fremtidens skole - Fornyelse av fag og kompetanser. Henta frå https://www.regjeringen.no/no/dokumenter/nou-20158/id2417001/

Olson, D.R. (2006). Oral discourse in a world of literacy. Research in the Teaching of English, 41(2), 136-143.

Ong, W.J. (1990). Muntlig och skriftlig kultur: teknologiseringen av ordet. Göteborg: Anthropos.

Pellowski, A. (1990). The World of Storytelling. Bronx N.Y.: The H.W. Wilson Company.

Postholm, M.B. (2005). Kvalitativ metode. Oslo: Universitetsforlaget.

Samset, H. (2010). Bibelfortellerboka : kino $i$ hodet til barn og unge. Oslo: Verbum.

Sturm, B.W. (1999). The enchanted imagination: Storytelling's power to entrance listeners. School Library Media Research, 2(6), 1-21. 
Sturm, B.W. (2000). The "storylistening" trance experience. Journal of American folklore, 113 (449), 287-304. DOI: 10.2307/542104

Sturm, B.W. (2002). Lost in a Story: Modeling Storytelling and Storylistening. I: I. M. Blayer \& M. Sánchez (red.). Storytelling: interdisciplinary \& intercultural perspectives. New York: Peter Lang.

Sturm, B.W. (2008). The process of sharing stories with young people. Knowledge Quest, 36(5), 12-18.

Svenkerud, S. (2013). «Ikke stå som en slapp potet» - elevsynspunkter på opplæring i muntlige ferdigheter. Acta Didactica Norge, 7(1), (Art. 2, 16 sider). DOI: https://doi.org/10.5617/adno.1109

Swann, J. (2002). A Man Amongst Men: The Intersection of Verbal, Visual, and Vocal Elements in an Oral Narrative. I: I. M. Blayer \& M. Sánchez (red.). Storytelling: interdisciplinary \& intercultural perspectives, (145161) New York: Peter Lang.

Säljö, R. (2006). Laring og kulturelle redskaper : om lareprosesser og den kollektive hukommelsen. Oslo: Cappelen akademisk forlag

Utdanningsdirektoratet. (2006, 2013, 2020). Lareplanverket for kunnskapsløftet. Henta frå https://www.udir.no/lk20/lareplanverket/

Utdanningsdirektoratet. (2013). Lareplan i norsk (NOR1-05). Henta frå http://data.udir.no/kl06/NOR1-05.pdf

Utdanningsdirektoratet. (2017). Rammeverk for grunnleggende ferdigheter.

Henta frå https://www.udir.no/laring-og-trivsel/lareplanverket/grunnleggende-ferdigheter/rammeverk-for-grunnleggende-ferdigheter/

Van der Veer, R. \& Valsiner, J. (1988). Lev Vygotsky and Pierre Janet: On the origin of the concept of sociogenesis. Developmental Review, 8(1), 5265. https://doi.org/http://dx.doi.org/10.1016/0273-2297(88)90011-1

Vettenranta, S. (2005). En fenomenologisk reise inn i de unges livsverden. I M. B. Postholm (red.). Kvalitativ metode. En innforing med fokus på fenomenologi, etnografi og kasusstudier. (159-175) Oslo: Universitetsforlsget. Vygotsky, L.S. (1978). Mind in society : the development of higher psychological processes. Cambridge, Mass: Harvard University Press.

Vygotsky, L.S. (2004). Imagination and creativity in childhood. Journal of Russian \& East European Psychology, 42(1), 7-97.

Aadland-Atkinson, K. \& Stuedahl, D. (2020). Elements of fairy tales and co-construction of meaning. Under utarbeiding. 
Aadland, K. (2009). Motivasjon til å forstå og bruka språket. Språkutvikling gjennom munnleg forteljing. Artikkelsamling. Rapporter, prosjektpresentasjoner og artikler utgitt $i$ forbindelse med konferansen Skapende laring 2009. Oslo: Musikk i skolen.

Aadland, K. (2016). The Performative Relation Between Storyteller, Story, and Children. I: O. Erstad, Kumpulainen, K.; Mäkitalo, Å.; Schrøder, K.Ch.; Pruulmann-Vengerfeldt, P.; Johannsdottir, T. (red.). Learning across Contexts in the Knowledge Society (s. 61-84). Rotterdam/Boston/Taipei: Sense Publishers. Doi: 10.1007/978-94-6300-414-5_4 